\title{
Adoption of a Turn Conformation Drives the Binding Affinity of p53 C-Terminal Domain Peptides to 14-3-30
}

\section{Supporting Information}

Ave Kuusk ${ }^{1,2 \ddagger}$, João Filipe Neves ${ }^{3 \ddagger}$, Kenny Bravo Rodriguez ${ }^{4,5 \ddagger}$, Anders Gunnarsson ${ }^{1}$, Yasser B. Ruiz-Blanco ${ }^{4}$, Michael Ehrmann ${ }^{5}$, Hongming Chen ${ }^{1,6}$, Isabelle Landrieu ${ }^{3,{ }^{*}}$, Elsa Sanchez-Garcia ${ }^{4,}$, , Helen Boyd ${ }^{7,},{ }^{*}$, Christian Ottmann $2,8,{ }^{*}$, Richard G. Doveston ${ }^{9,{ }^{*}}$

${ }^{1}$ Discovery Sciences, IMED Biotech Unit, AstraZeneca, Mölndal, Sweden

2 Laboratory of Chemical Biology, Department of Biomedical Engineering and Institute for Complex Molecular Systems, Eindhoven University of Technology, The Netherlands

${ }^{3}$ Lille University UMR 8576 CNRS, 59000 Lille, France

${ }^{4}$ Department of Computational Biochemistry, Center of Medical Biotechnology, University of DuisburgEssen, Germany

${ }^{5}$ Department of Microbiology, University of Duisburg-Essen, Germany

${ }^{6}$ Chemistry and Chemical Biology Centre, Guangzhou Regenerative Medicine and Health-Guangdong Laboratory, Guangzhou, China

${ }^{7}$ Drug Safety and Metabolism, IMED Biotech Unit, AstraZeneca, Cambridge, UK

${ }^{8}$ Department of Chemistry, University of Duisburg-Essen, Germany

${ }^{9}$ Leicester Institute of Structural and Chemical Biology and Department of Chemistry, University of Leicester, University Road, Leicester LE1 7RH, UK 


\section{Table of Contents}

Figure S1. ITC titration curves of 9mer, 12mer, 14mer, 15mer, $20 \mathrm{mer}$ and 32mer peptides of p53.

Figure S2. ${ }^{1} \mathrm{H}-{ }^{15} \mathrm{~N}$ TROSY-HSQC spectra of $15 \mathrm{~N} 13 \mathrm{C} 2 \mathrm{H}$ labelled $14-3-3 \sigma \Delta \mathrm{C} 17$ in the presence of 553 peptides.

Figure S3. p53 peptides interact with 14-3-3 through the amphipathic binding groove. .............. 5

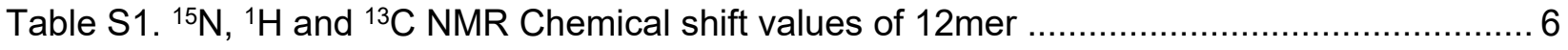

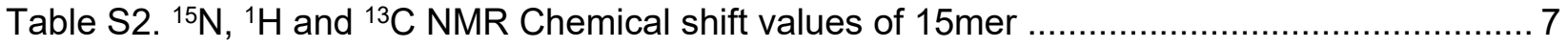

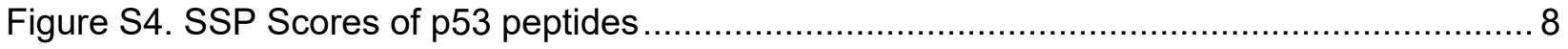

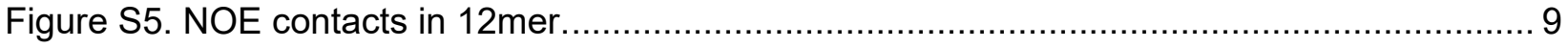

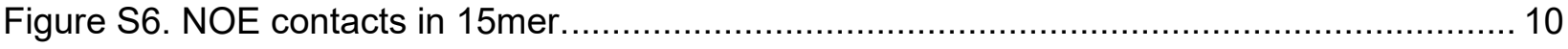

Figure S7. Convergence analysis of the PMF profiles for the ten windows splitting along pulling trajectories of the 15mer (left) and 12mer (right).....

Table S3. Different contributions to the final binding free energies of the $15 \mathrm{mer}$ and $12 \mathrm{mer}$ in $\mathrm{kcal} / \mathrm{mol}$.

Figure S8. RMSD values for the backbone atoms of residues Kp386 to Aspp391 during the MD simulations. The values shown are the average of the three MD replicas performed with the 12 mer and 15 mer peptides bound to $14-3-3 \sigma$.

Figure S9. Residue wise probability to find the peptide closer than $4 \AA$ to $14-3-3 \sigma$ residues ..... 12

Table S4. Average distances $(\AA)$ for selected interactions............................................. 13

Figure S10. Structure of the bound conformation of the 12 mer peptide. .............................. 13

Figure S11. Time evolution of the PMF profiles for the 15mer (left) and 12mer (right)............ 14

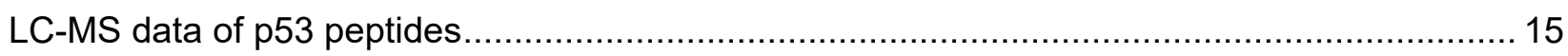

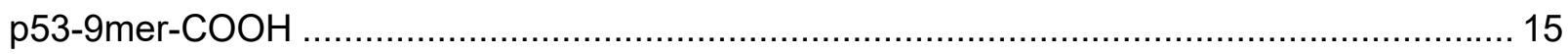

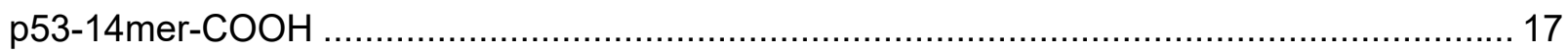

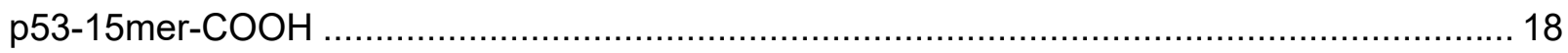

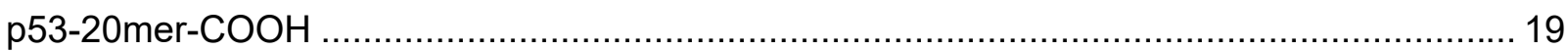



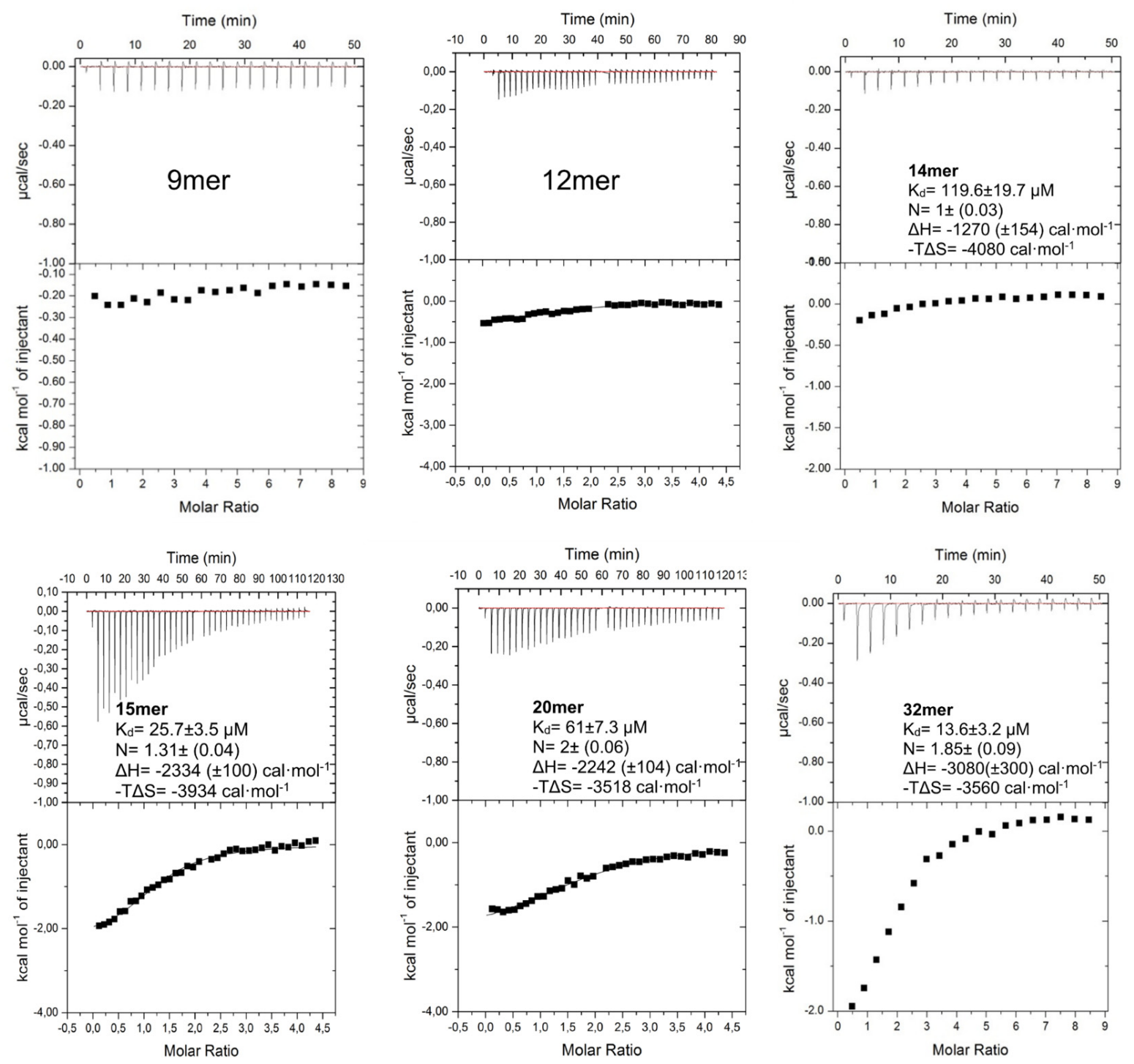

Figure S1. ITC titration curves of 9mer, 12mer, 14mer, 15mer, $20 \mathrm{mer}$ and 32mer peptides of p53. 

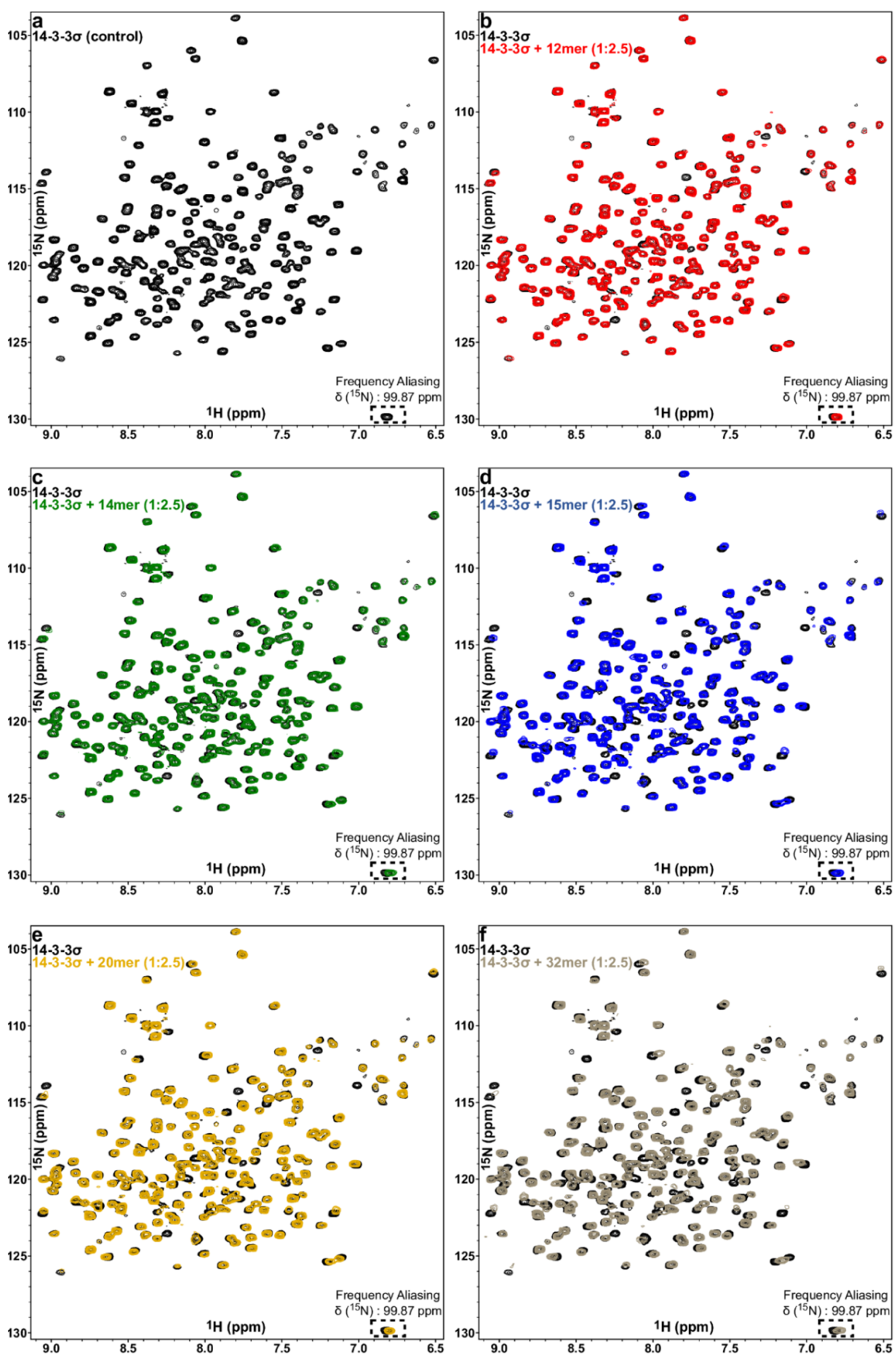

Figure S2. ${ }^{1} \mathrm{H}-{ }^{15} \mathrm{~N}$ TROSY-HSQC spectra of $15 \mathrm{~N} 13 \mathrm{C} 2 \mathrm{H}$ labelled $14-3-3 \sigma \Delta \mathrm{C} 17$ in the presence of p53 peptides. The spectra of $100 \mu \mathrm{M}{ }^{15} \mathrm{~N}^{13} \mathrm{C}^{2} \mathrm{H}$ labelled $14-3-3 \sigma \Delta \mathrm{C} 17$ alone is shown in $\mathrm{A}$ (in black). The spectra of $100 \mu \mathrm{M}{ }^{15} \mathrm{~N}^{13} \mathrm{C}^{2} \mathrm{H}$

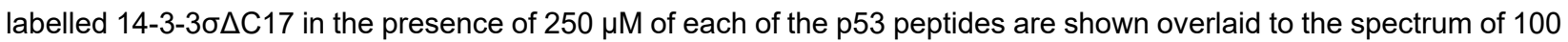

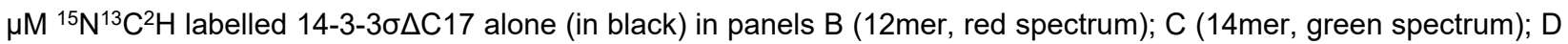
(15mer, blue spectrum); E (20mer, yellow spectrum) and $F$ (32mer, grey spectrum). 


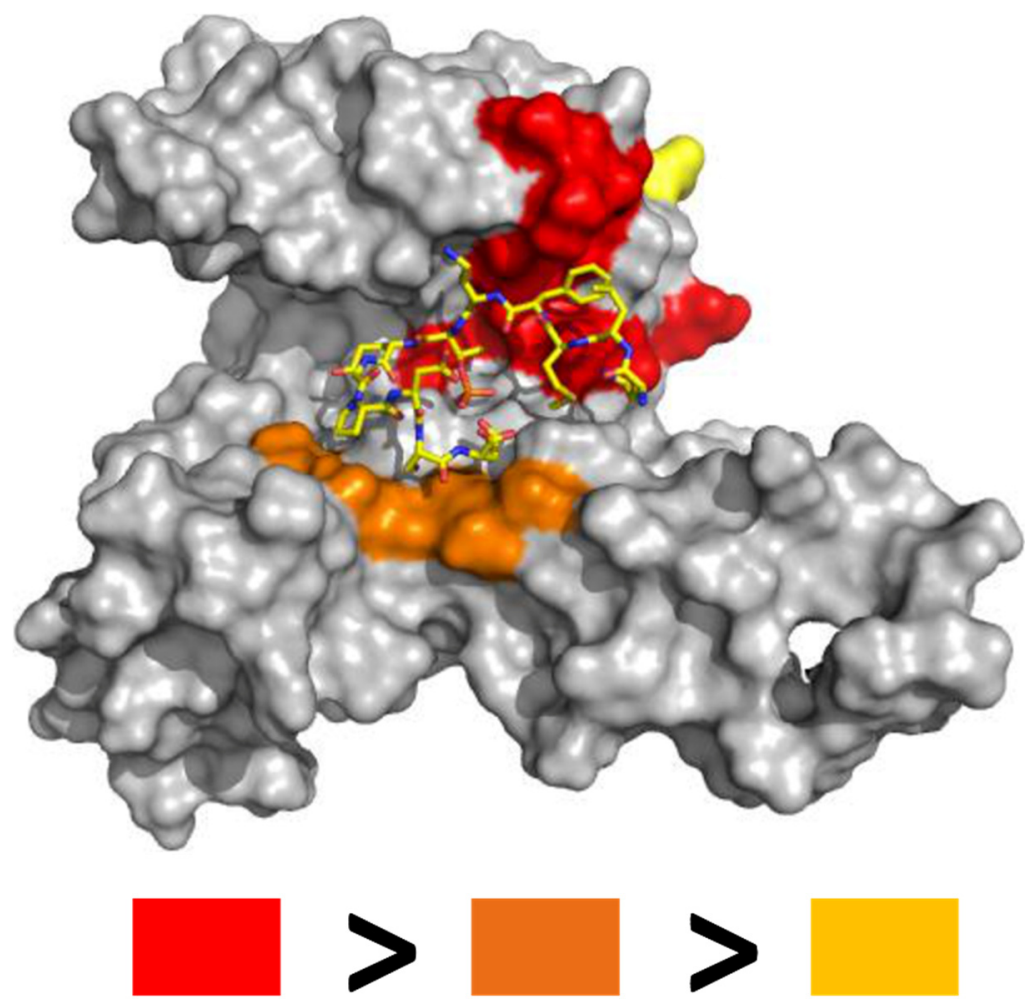

Figure S3. p53 peptides interact with 14-3-3 through the amphipathic binding groove. Mapping on the crystal structure of 14-3-3 $\sigma \Delta \mathrm{C} 17$ in complex with 12mer (PDB ID: $5 \mathrm{MHC}$ ) of the amino acid residues whose correspondent correlation peak intensities were the most affected by the presence of $12 \mathrm{mer}$. The 1-10 residues whose correspondent correlation peak intensities were the most affected are colored in red, the 11-20 are colored in brown and the 20-25 are colored in yellow. The results for $14 \mathrm{mer}, 15 \mathrm{mer}, 20 \mathrm{mer}$ and $32 \mathrm{mer}$ were identical. 
Table S1. ${ }^{15} \mathrm{~N},{ }^{1} \mathrm{H}$ and ${ }^{13} \mathrm{C}$ NMR Chemical shift values of $12 \mathrm{mer}$ in $100 \mathrm{mM}$ Sodium Phosphate, $50 \mathrm{mM} \mathrm{NaCl}, \mathrm{pH} 6.8$ at $4^{\circ} \mathrm{C}$

\begin{tabular}{|c|c|c|c|c|c|c|}
\hline & $\delta\left({ }^{15} \mathrm{~N}\right)$ & $\delta\left({ }^{1} \mathrm{H}\right)[$ & & & $\delta\left({ }^{13} \mathrm{C}\right)$ & \\
\hline & $\mathrm{N}$ & $\mathrm{HN}$ & $\mathrm{H}_{a}$ & $\mathrm{H}_{\beta}$ & $\mathrm{C}_{\alpha}$ & $\mathrm{C}_{\beta}$ \\
\hline K382 & - & - & - & - & - & - \\
\hline L383 & 125.2 & 8.798 & 4.317 & $\begin{array}{l}1.478 \\
1.611\end{array}$ & 55.39 & 42.19 \\
\hline M384 & 122.2 & 8.560 & 4.447 & $\begin{array}{l}1.923, \\
1.924\end{array}$ & 54.95 & 32.82 \\
\hline F385 & 121.5 & 8.351 & 4.633 & $\begin{array}{l}2.982, \\
3.132\end{array}$ & 57.53 & 39.92 \\
\hline K386 & 123.9 & 8.335 & 4.350 & $\begin{array}{l}1.729 \\
1.802\end{array}$ & 55.92 & 33.55 \\
\hline pT387 & 121.3 & 9.306 & 4.167 & 4.402 & 63.27 & 72.41 \\
\hline E388 & 125.4 & 8.857 & 4.342 & $\begin{array}{l}1.966, \\
2.053\end{array}$ & 56.59 & 30.48 \\
\hline G389 & 110.9 & 8.467 & $\begin{array}{l}4.079, \\
4.167\end{array}$ & - & 44.69 & - \\
\hline P390 & - & - & 4.450 & $\begin{array}{l}1.974, \\
2.2267\end{array}$ & 63.21 & 32.32 \\
\hline D391 & 120.7 & 8.617 & 4.639 & $\begin{array}{l}2.611 \\
2.748\end{array}$ & 54.45 & 41.04 \\
\hline S392 & 116.3 & 8.287 & 4.456 & $\begin{array}{l}3.835 \\
3.890\end{array}$ & 58.25 & 64.27 \\
\hline D393 & 128.0 & 8.196 & 4.401 & $\begin{array}{l}2.579, \\
2.672\end{array}$ & 56.10 & 41.98 \\
\hline
\end{tabular}


Table S2. ${ }^{15} \mathrm{~N},{ }^{1} \mathrm{H}$ and ${ }^{13} \mathrm{C}$ NMR Chemical shift values of $15 \mathrm{mer}$ in $100 \mathrm{mM}$ Sodium Phosphate, $50 \mathrm{mM} \mathrm{NaCl}, \mathrm{pH} 6.8$ at $4^{\circ} \mathrm{C}$.

\begin{tabular}{|c|c|c|c|c|c|c|}
\hline & $\delta\left({ }^{15} \mathrm{~N}\right)$ & & $\delta\left({ }^{1} \mathrm{H}\right)[\mathrm{r}$ & & & [ppm] \\
\hline & $\mathrm{N}$ & $\mathrm{HN}$ & $\mathrm{H}_{\alpha}$ & $\mathrm{H}_{\beta}$ & $\mathrm{C}_{\alpha}$ & $\mathrm{C}_{\beta}$ \\
\hline R379 & - & - & - & - & - & - \\
\hline H380 & - & - & - & - & - & - \\
\hline K381 & 124.3 & 8.766 & 4.260 & $\begin{array}{l}1.734, \\
1.788\end{array}$ & $56.46^{*}$ & $33.17^{*}$ \\
\hline K382 & 123.7 & 8.671 & 4.257 & $\begin{array}{l}1.753 \\
1.792\end{array}$ & $56.46^{*}$ & $33.17^{*}$ \\
\hline L383 & 124.1 & 8.494 & 4.292 & $\begin{array}{l}1.484 \\
1.640\end{array}$ & 55.06 & 42.18 \\
\hline M384 & 120.7 & 8.379 & 4.402 & $\begin{array}{l}1.913 \\
1.913\end{array}$ & 56.02 & 32.67 \\
\hline F385 & 120.8 & 8.294 & 4.622 & $\begin{array}{l}2.987 \\
3.151\end{array}$ & 57.45 & 39.81 \\
\hline K386 & 123.1 & 8.258 & 4.343 & $\begin{array}{l}1.732, \\
1.805\end{array}$ & 55.97 & 33.17 \\
\hline pT387 & 121.1 & 9.312 & 4.167 & 4.399 & 63.26 & 72.36 \\
\hline E388 & 125.2 & 8.864 & 4.347 & $\begin{array}{l}1.963 \\
2.105\end{array}$ & 56.68 & 30.47 \\
\hline G389 & 110.7 & 8.464 & $\begin{array}{l}4.112, \\
4.096\end{array}$ & - & 44.73 & - \\
\hline P390 & - & - & 4.448 & 2.213 & 63.20 & 32.28 \\
\hline D391 & 120.5 & 8.618 & 4.638 & $\begin{array}{l}2.615 \\
2.748\end{array}$ & 54.44 & 41.01 \\
\hline S392 & 116.1 & 8.278 & 4.453 & $\begin{array}{l}3.832, \\
3.892\end{array}$ & 58.20 & 64.19 \\
\hline D393 & 127.8 & 8.197 & 4.400 & $\begin{array}{l}2.587 \\
2.676\end{array}$ & 55.01 & 41.98 \\
\hline
\end{tabular}


a SSP Score 12mer
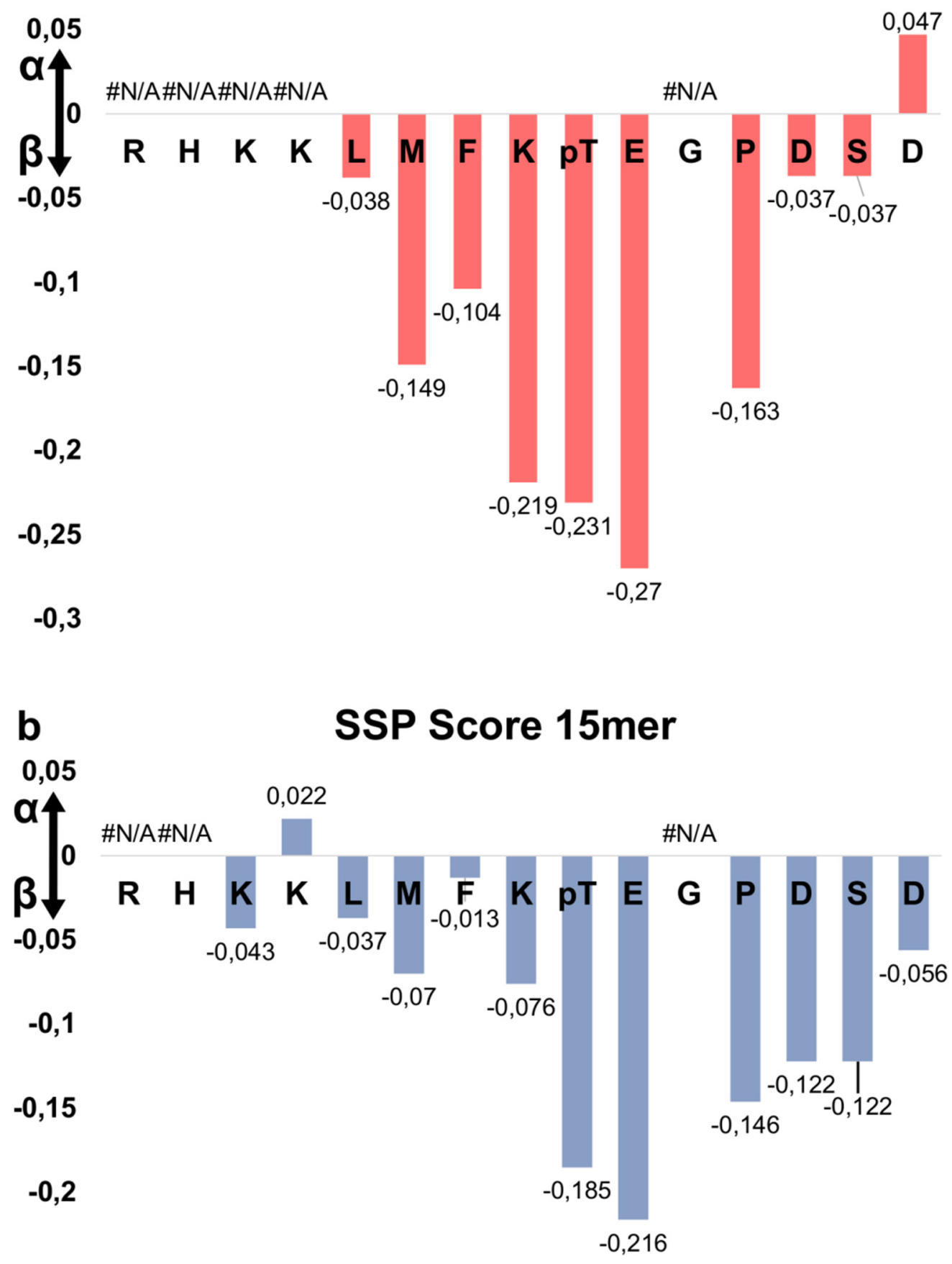

$-0,25$

$-0,3$

Figure S4. SSP Scores of p53 peptides reveal a predominantly disordered structure with a small tendency to $\beta$-strand. The plots of SSP scores for the 12mer and 15mer are shown in A and B respectively. The bars represent the chemical shift indexes ( $\sim 1$ for $\alpha$-helix, $\sim 0$ for random coil, $\sim-1$ for $\beta$-strand). The SSP score for G389 was not calculated since residues preceding a proline are usually outliers. 

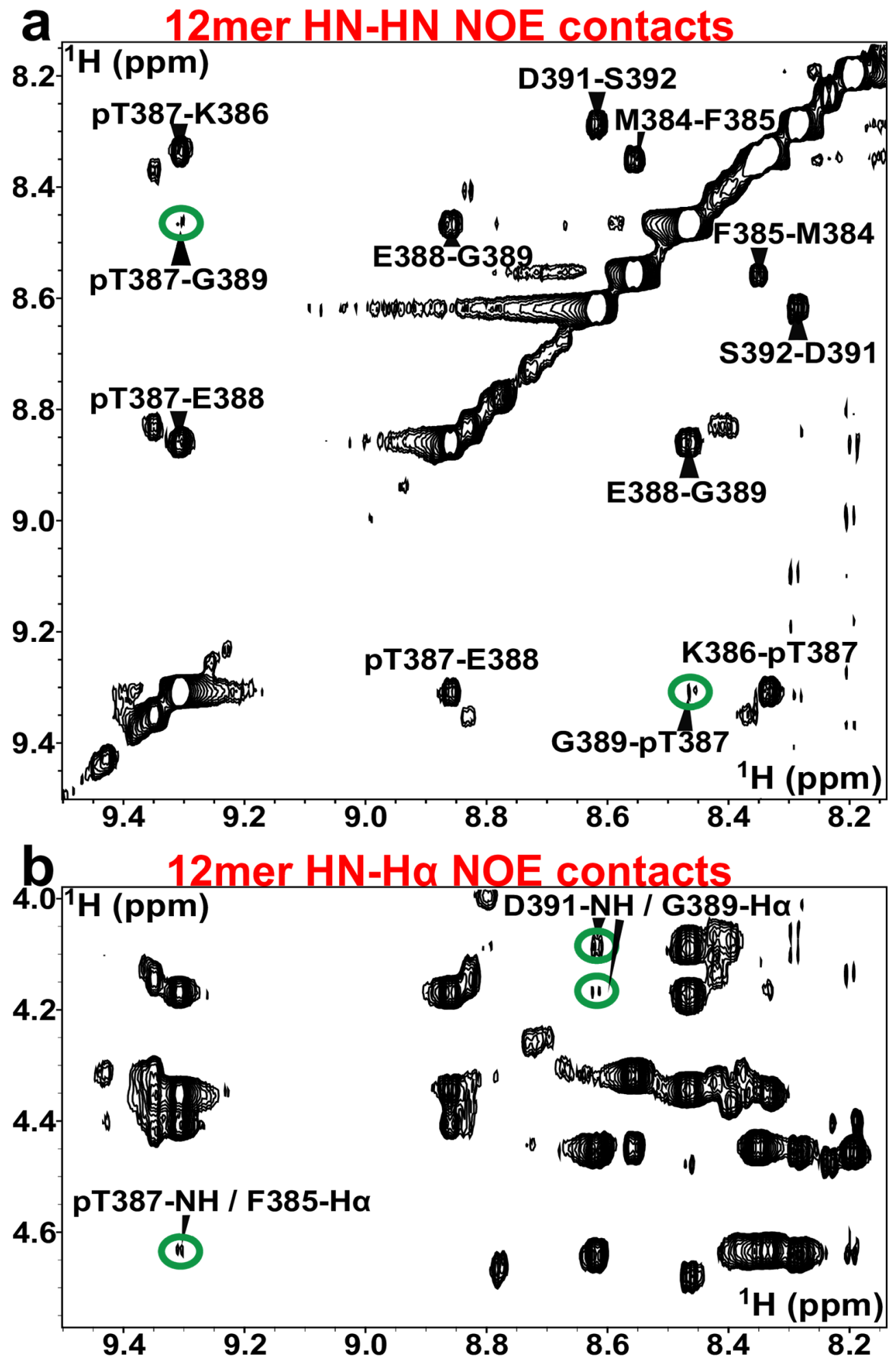

Figure S5. NOE contacts in 12mer. (A) Section of the NOESY spectrum of $12 \mathrm{mer}$ where it is possible to see the HNHN NOE peaks. Only the majoritarian forms are assigned. The medium-range NOEs are identified with a green circle. (B) Section of the NOESY spectrum of 12 mer where it is possible to see the HN-Ha NOE peaks. Only the mediumrange NOEs are assigned and are identified with a green circle. The NOE summary diagram is presented in Figure 4 of the manuscript. 

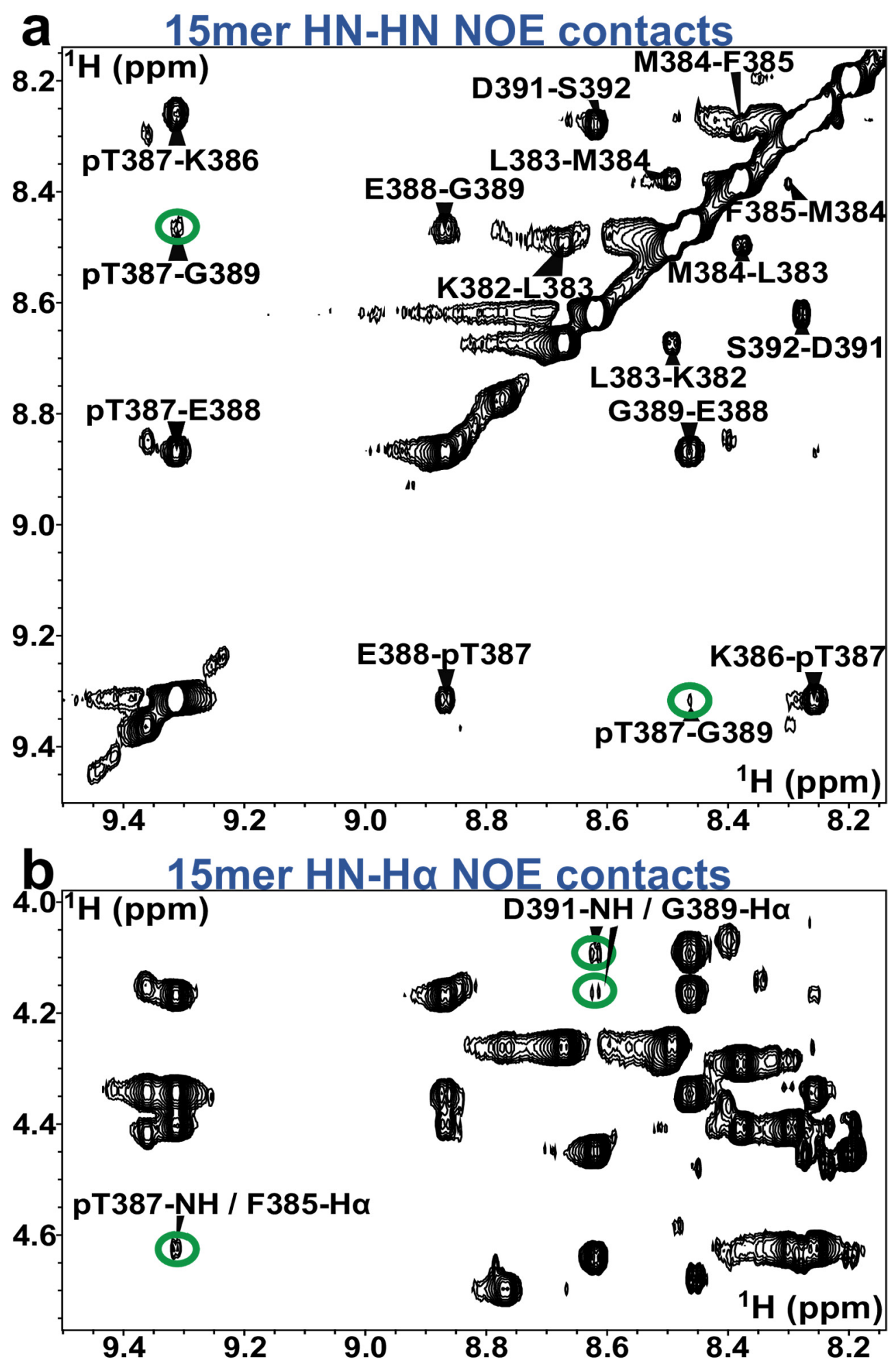

Figure S6. NOE contacts in 15mer. (A) Section of the NOESY spectrum of $15 \mathrm{mer}$ where it is possible to see the HNHN NOE peaks. Only the major forms are assigned. The medium-range NOEs are identified with a green circle. (B) Section of the NOESY spectrum of 15 mer where it is possible to see the HN-Ha NOE peaks. Only the medium-range NOEs are assigned and are identified with a green circle. The NOE summary diagram is presented in Figure 4 of the manuscript. 


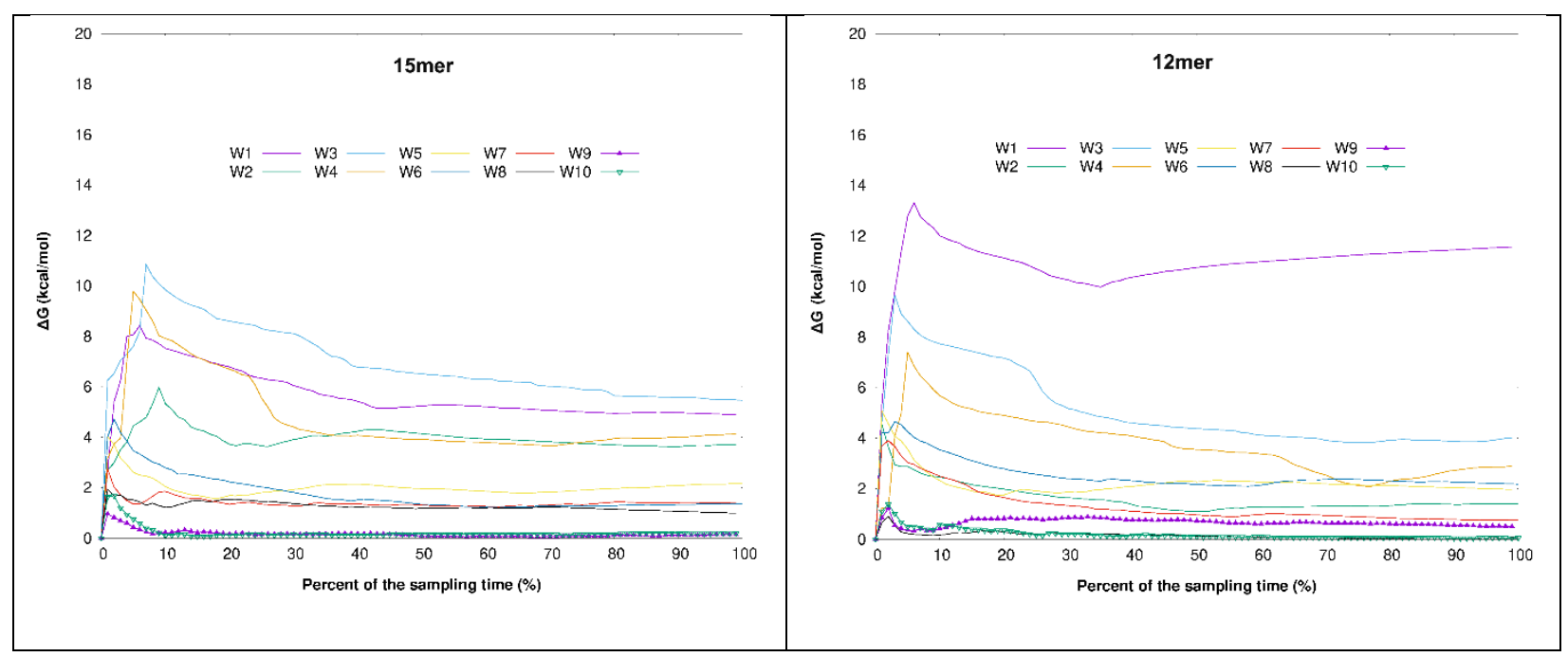

Figure S7. Convergence analysis of the PMF profiles for the ten windows splitting along pulling trajectories of the $15 \mathrm{mer}$ (left) and $12 \mathrm{mer}$ (right). Each window covers $2 \AA$ of separation between the center of masses of the protein and the peptides. The norms of the PMF profiles at different fractions of the simulations are used to monitor their convergence. The norm values should remain steady once the convergence is achieved. It is observed that above $50 \%$ of the trajectory the variations of the PMF norms are in the order of $1 \mathrm{kcal} / \mathrm{mol}$, thus the convergence of the pulling PMFs are validated.

Table S3. Different contributions to the final binding free energies of the $15 \mathrm{mer}$ and $12 \mathrm{mer}$ in $\mathrm{kcal} / \mathrm{mol}$.

\begin{tabular}{l|rr} 
& 15MER & 12MER \\
\hline CONFORMATIONAL CONSTRAINT IN BOUND STATE & -20.69 & -8.96 \\
SUM OF ORIENTATION CONSTRAINTS IN BOUND STATE & -0.98 & -1.06 \\
LIGAND PULLING CONTRIBUTION & -33.51 & -21.35 \\
CONFORMATIONAL CONSTRAINT IN UNBOUND STATE & 39.89 & 18.17 \\
ORIENTATION CONSTRAINTS IN UNBOUND STATE & 6.61 & 6.61 \\
TOTAL BINDING FREE ENERGY & -8.68 & -6.59
\end{tabular}

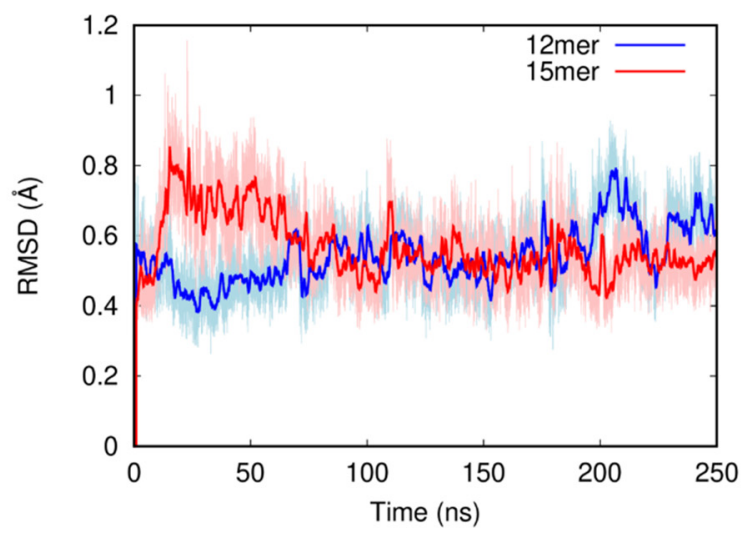


Figure S8. RMSD values for the backbone atoms of residues Kp386 to Aspp391 during the MD simulations. The values shown are the average of the three MD replicas performed with the $12 \mathrm{mer}$ and $15 \mathrm{mer}$ peptides bound to $14-3-3 \sigma$.

$12 \mathrm{M}(4 \AA)$

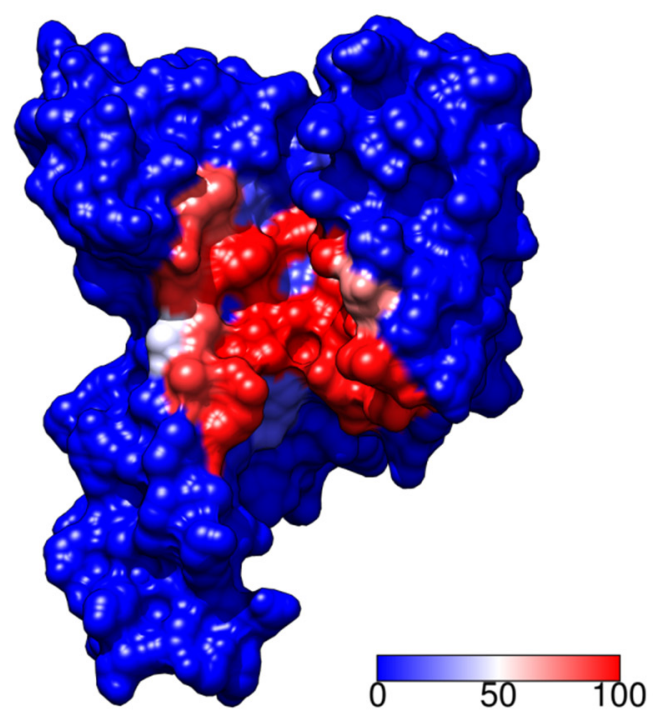

$15 \mathrm{M}(4 \AA)$

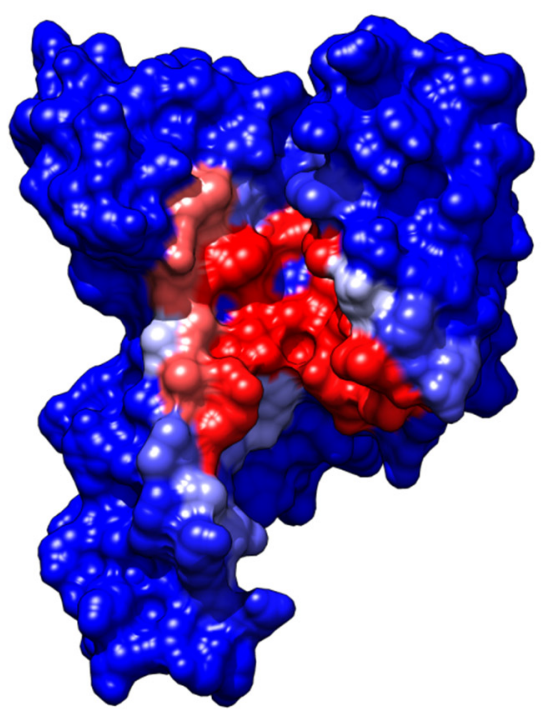

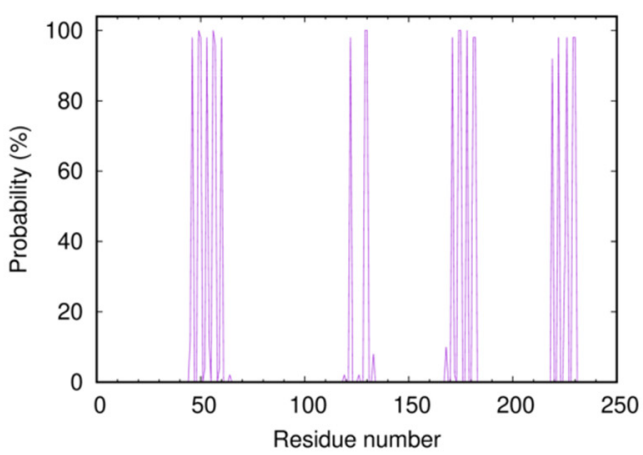

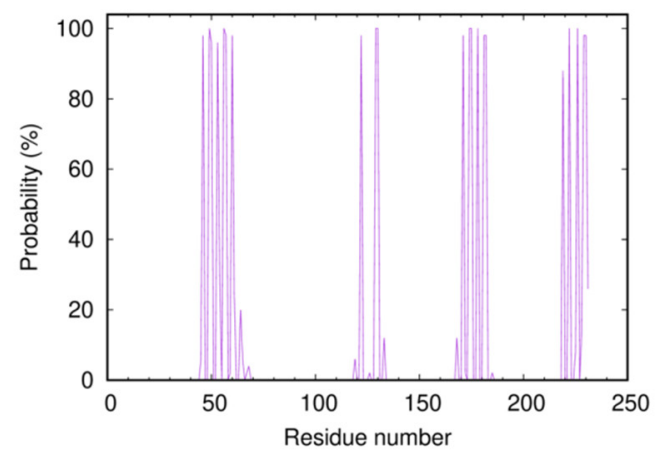

Figure S9. Residue wise probability to find the peptide closer than $4 \AA$ to $14-3-3 \sigma$ residues. The values shown are averaged over the three replicas of the MD simulations. 
Table S4. Average distances $(\AA)$ for selected interactions. Population values are given for conformations in which the corresponding distance takes values below $4.0 \AA$. The atoms used to measure the distances are given in the name of the interaction as superscripts. Three independent replicas of the simulations are considered.

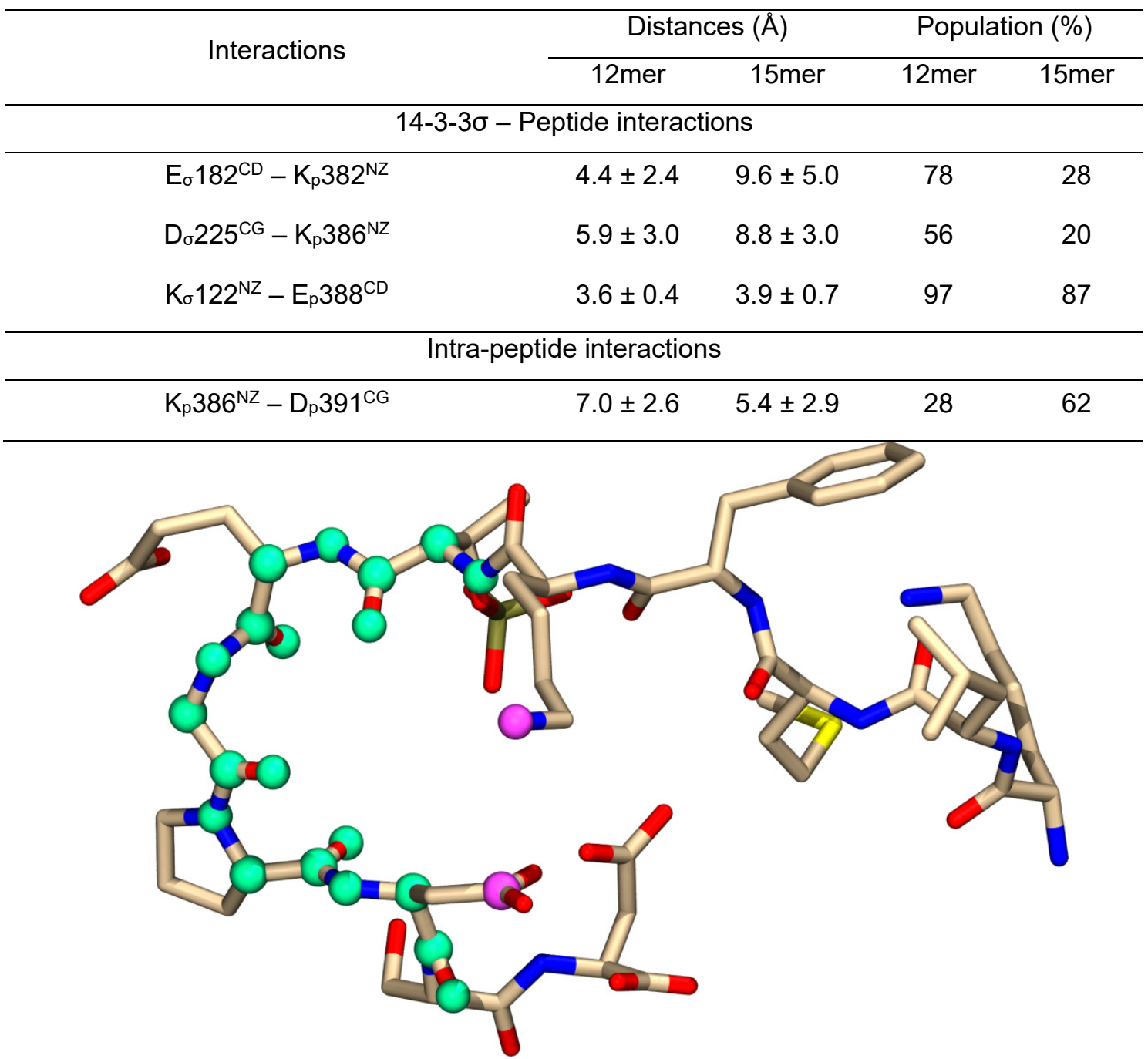

Figure S10. Structure of the bound conformation of the $12 \mathrm{mer}$ peptide. Atoms used to define the collective variable used in the ABF calculations are highlighted as green spheres. Atoms involved in the important interaction between Kp386NZ and Dp391CG are highlighted as pink spheres. 

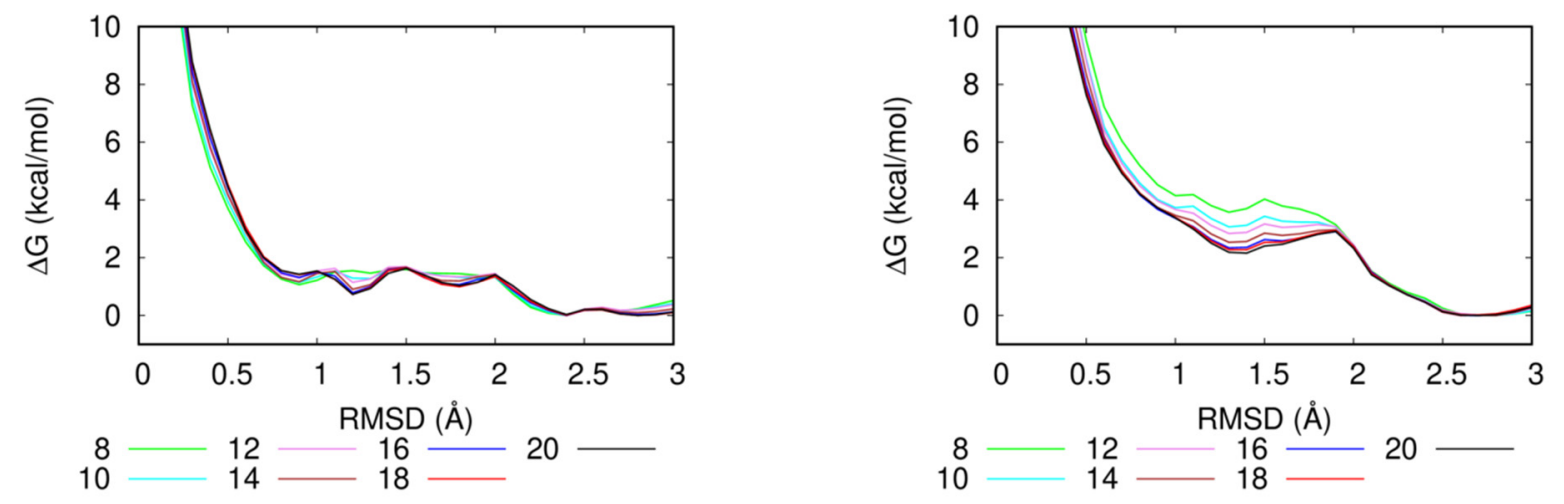

Figure S11. Time evolution of the PMF profiles for the $15 \mathrm{mer}$ (left) and 12mer (right). The PMF was plotted for a simulated time of $8,10,12,14,16,18$ and 20 ns per window. 


\section{LC-MS data of $\mathrm{p} 53$ peptides}

\section{p53-9mer-COOH}

\section{$\mathrm{H}_{2} \mathrm{~N}-\mathrm{FK}(\mathrm{pT})$ EGPDSD-COOH}

Chemical Formula: $\mathrm{C}_{42} \mathrm{H}_{63} \mathrm{~N}_{10} \mathrm{O}_{21} \mathrm{P}$

Exact Mass: 1074.39

Molecular Weight: 1074.99

$\left[\mathrm{M}^{+\mathrm{H}}\right]$ : $1075.39(100.0 \%),\left[\mathrm{M}^{+2 \mathrm{H}}\right] 2+538.2 ;\left[\mathrm{M}^{+3 H}\right]^{3+} 359.1$

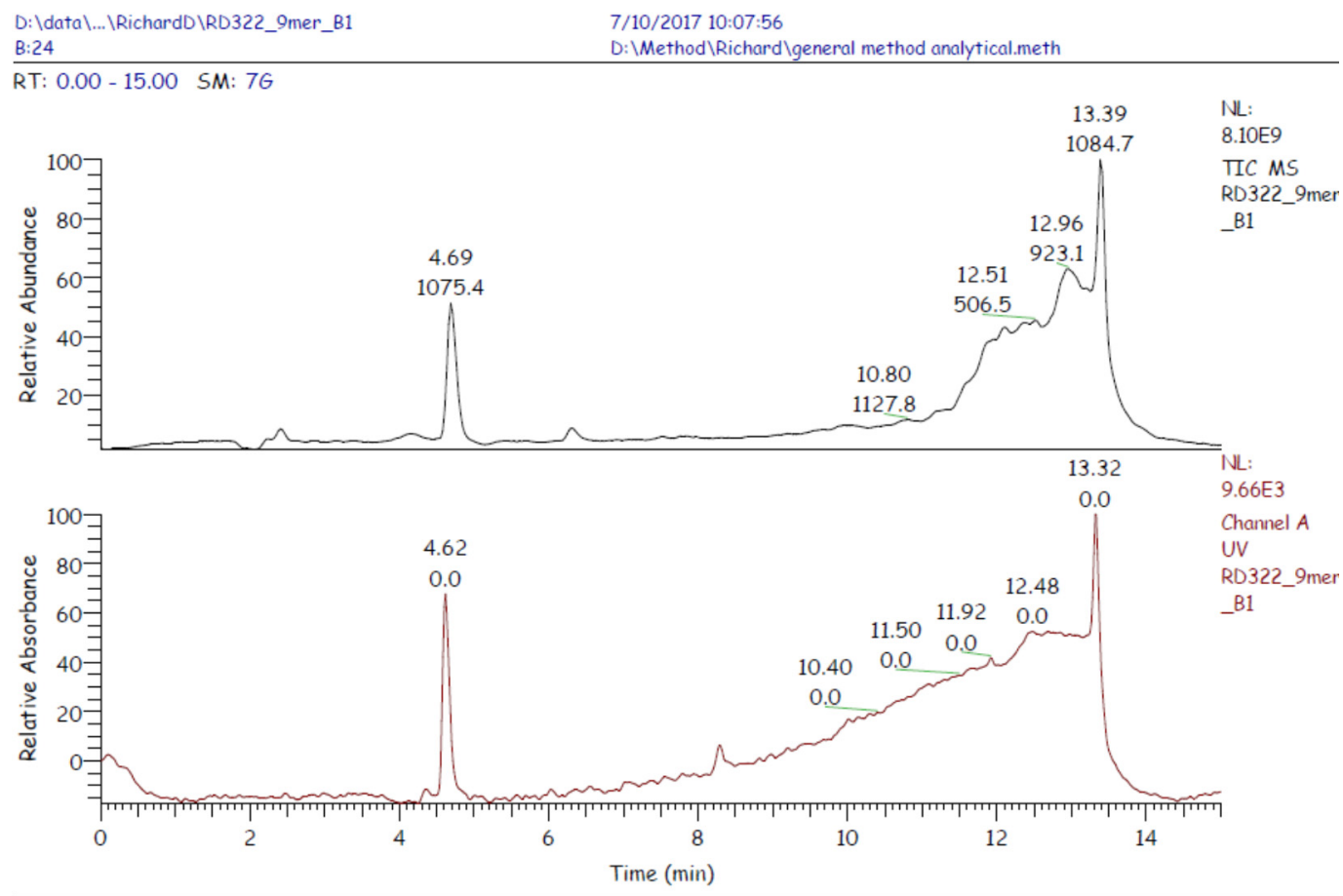

RD322_9mer_B1 \#167-183 RT: 4.47-4.90 AV: 17 SM: 5 G NL: $4.99 E 7$

T: + p ESI Full ms [110.00-2000.00]

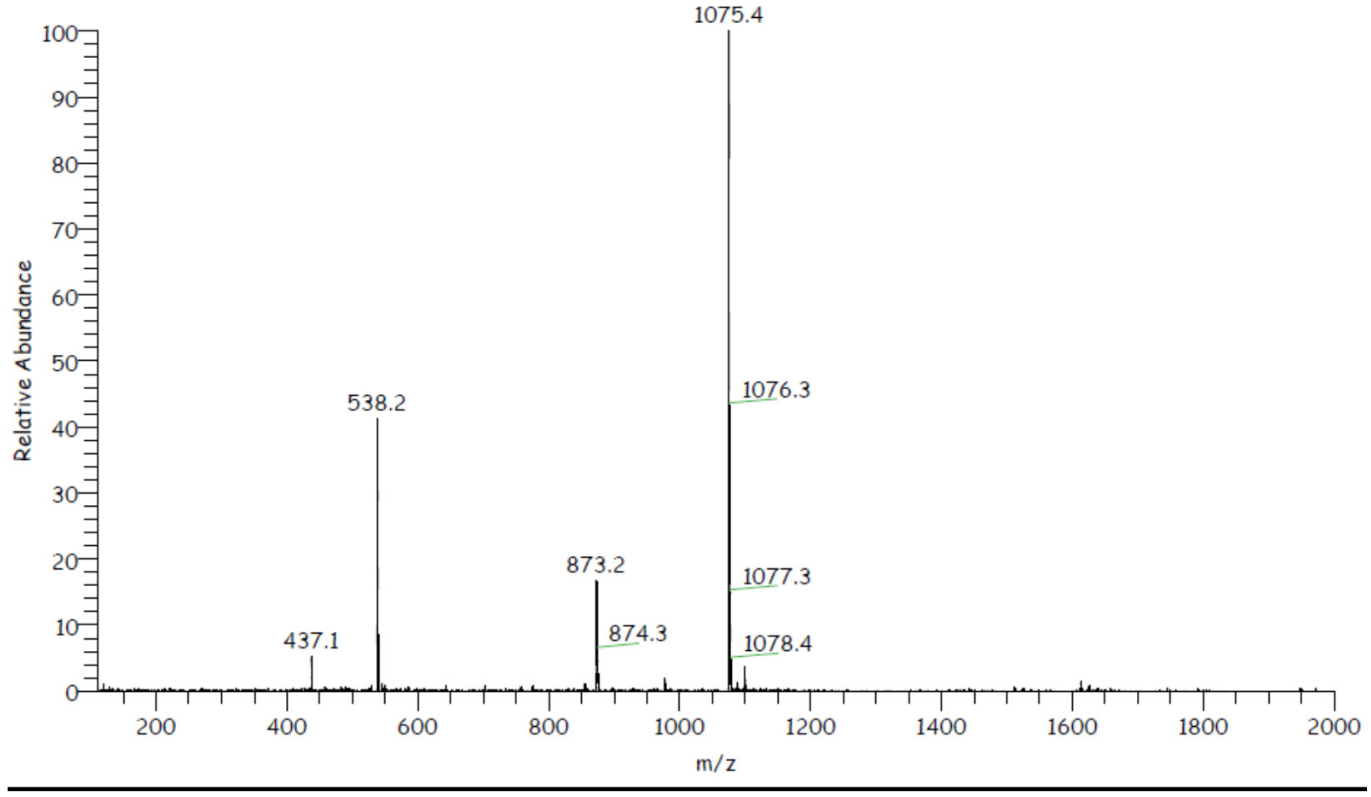


p53-12mer-COOH

$\mathrm{H}_{2} \mathrm{~N}-\mathrm{KLMFK}(\mathrm{pT}) \mathrm{EGPDSD}-\mathrm{OH}$

Chemical Formula: $\mathrm{C}_{59} \mathrm{H}_{95} \mathrm{~N}_{14} \mathrm{O}_{24} \mathrm{PS}$

Exact Mass: 1446.61

Molecular Weight: 1447.52

$\left[\mathrm{M}^{+\mathrm{H}}\right]: 1447.61$ (100.0\%), $\left[\mathrm{M}^{+2 \mathrm{H}}\right] 2+724.76 ;\left[\mathrm{M}^{+3 \mathrm{H}}\right]^{3+} 483.50$

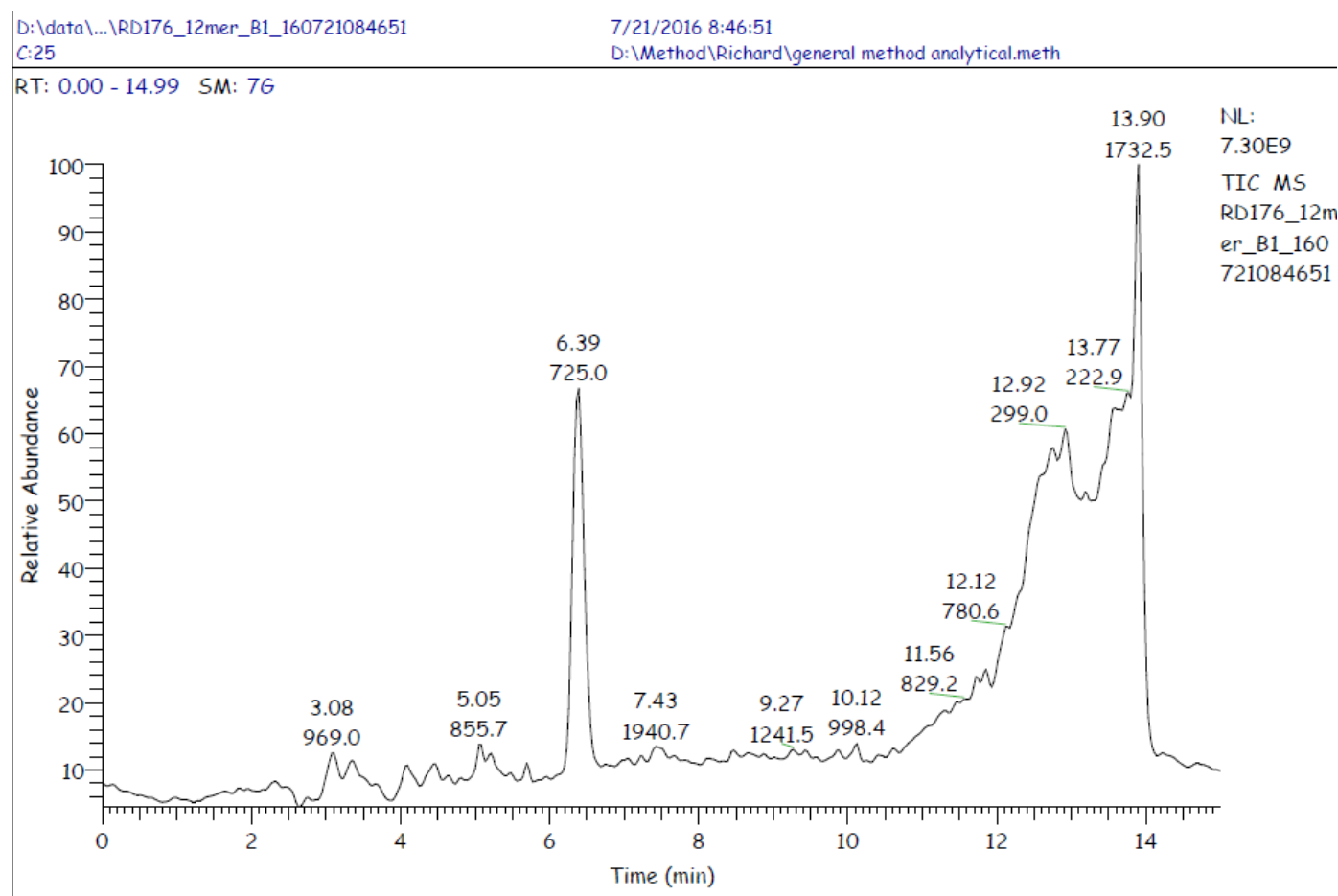

RD176_12mer_B1_160721084651 \#231-250 RT: 6.15-6.65 AV: 20 SM: 5 G NL: 2.86E7

$\mathrm{T}:$ + p ESI Full ms [110.00-2000.00]

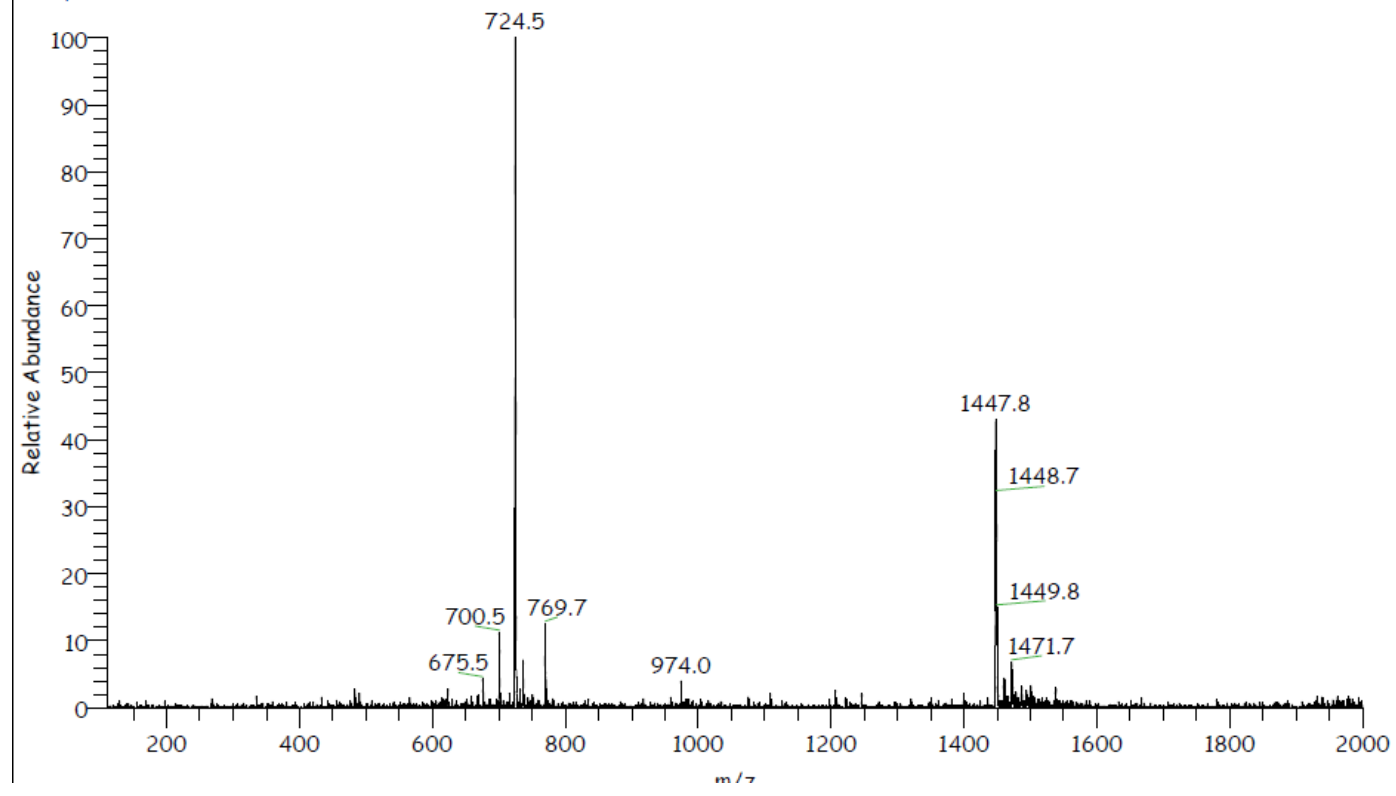


p53-14mer-COOH

\section{$\mathrm{H}_{2} \mathrm{~N}-\mathrm{HKKLMFK}(\mathrm{pT}) \mathrm{EGPDSD}-\mathrm{COOH}$ \\ Chemical Formula: $\mathrm{C}_{71} \mathrm{H}_{114} \mathrm{~N}_{19} \mathrm{O}_{26} P S$}

Exact Mass: 1711.76

Molecular Weight: 1712.83

$\left[\mathrm{M}^{+\mathrm{H}}\right]: 1712.76\left[\mathrm{M}^{+2 \mathrm{H}}\right]^{2+}: 857.4 ;\left[\mathrm{M}^{+3 \mathrm{H}}\right]^{3+}: 571.9$

$D: \backslash$ data $\backslash \ldots \backslash$ RichardD $\backslash$ RD 322_14mer_B1

B:26

7/10/2017 10:38:51

RT: $0.00-15.00 \quad S M: 7 G$ $D: \backslash$ Method $\backslash$ Richard $\backslash$ general method analytical.meth

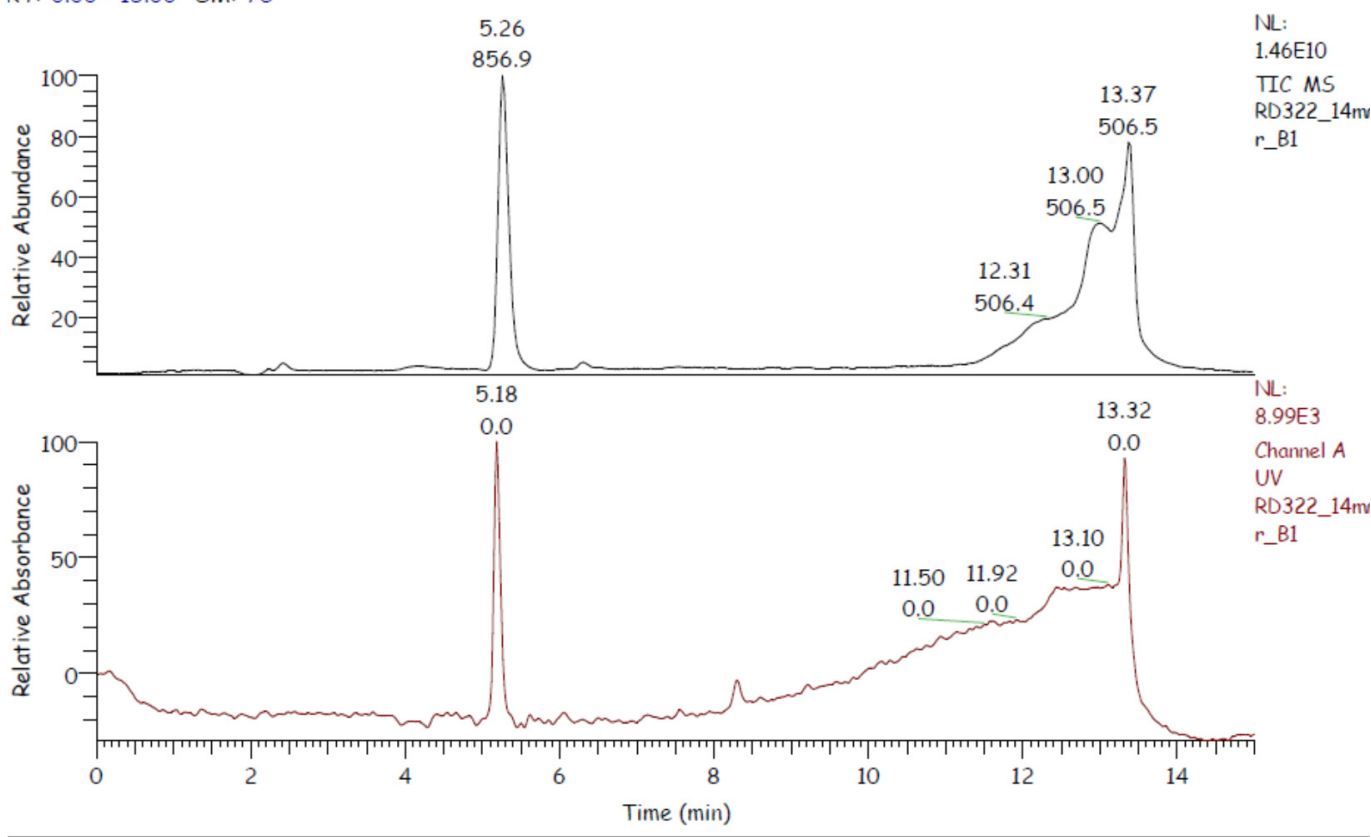

RD322_14mer_B1 \#186-204 RT: 4.99-5.47 AV: 19 SM: 5 G NL: 1.31E8

$\mathrm{T}:$ + p ESI Full ms [110.00-2000.00]

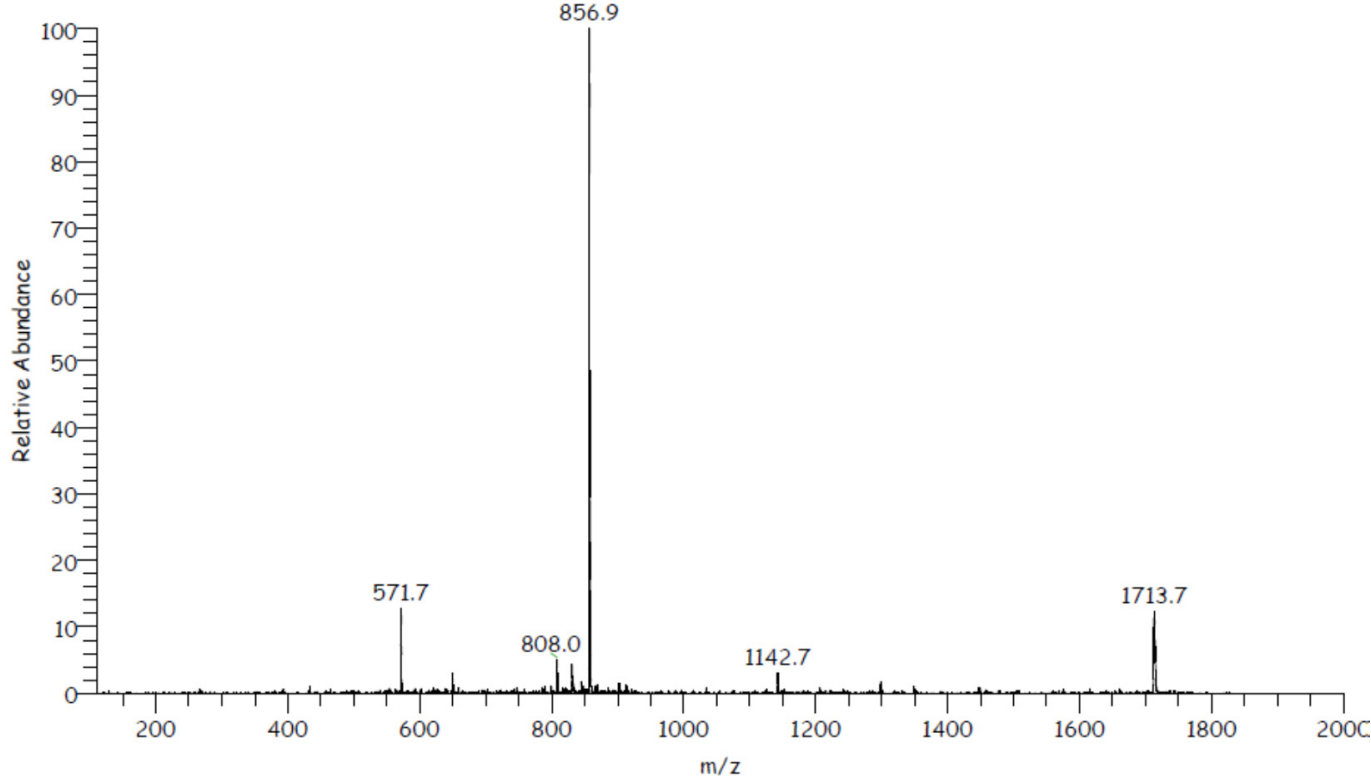


p53-15mer-COOH

\section{$\mathrm{H}_{2} \mathrm{~N}-\mathrm{RHKKLMFK}(\mathrm{pT})$ EGPDSD-COOH}

Chemical Formula: $\mathrm{C}_{77} \mathrm{H}_{126} \mathrm{~N}_{23} \mathrm{O}_{27} \mathrm{PS}$

Exact Mass: 1867.87

Molecular Weight: 1869.02

$\left[\mathrm{M}^{+\mathrm{H}}\right]: 1867.87$ (100.0\%); $\left[\mathrm{M}^{+2 \mathrm{H}}\right]^{2+}: 934.90 ;\left[\mathrm{M}^{+3 \mathrm{H}}\right]^{3+}: 623.62 ;\left[\mathrm{M}^{+4 \mathrm{H}}\right]^{4+}: 467.97$

D:Idata $\backslash .$. IRichard $\backslash R D 085 \_15$ mer_B1 8/5/2016 8:06:45

D:24 D: $\backslash$ Method $\backslash$ Richard $\backslash$ general method analytical.meth

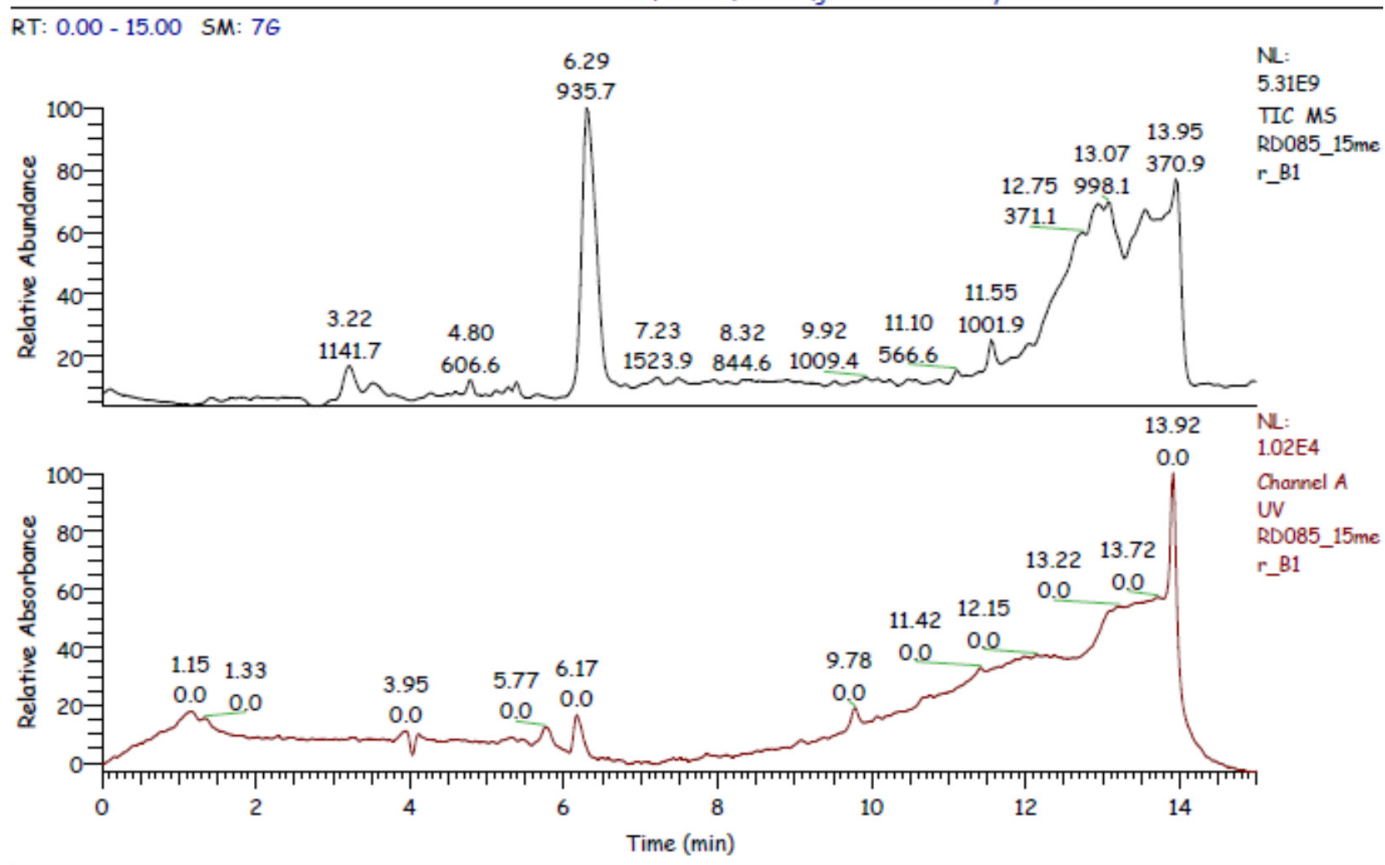

RD085_15mer_B1 \#226-246 RT: 6.03-6.56 AV: 21 SM: $5 G \quad$ NL: 4.56E7

$\mathrm{T}:+\mathrm{p}$ ESI Full ms [110.00-2000.00]

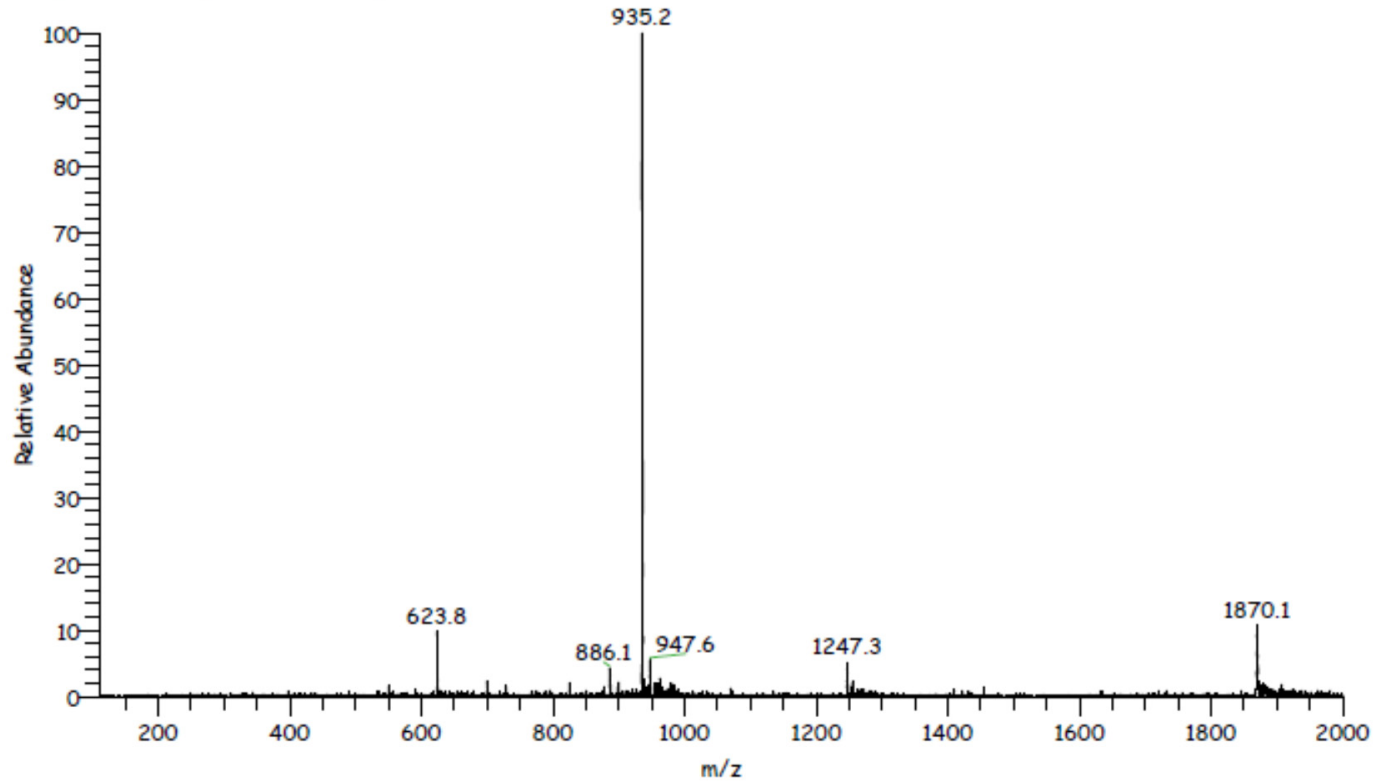


p53-20mer-COOH

\section{$\mathrm{H}_{2} \mathrm{~N}$-GQSTSRHKKLMFK(pT)EGPDSD-COOH}

Chemical Formula: $\mathrm{C}_{94} \mathrm{H}_{154} \mathrm{~N}_{29} \mathrm{O}_{36} \mathrm{PS}$

Exact Mass: 2328.06

Molecular Weight: 2329.47

$\left[\mathrm{M}^{+\mathrm{H}}\right]$ : 2329.06 (100.0\%); $\left[\mathrm{M}^{+2 \mathrm{H}}\right]^{2+:} 1165.03 ;\left[\mathrm{M}^{+3 \mathrm{H}}\right]^{3+}: 777.02 ;\left[\mathrm{M}^{+4 H}\right]^{4+}: 583.02$

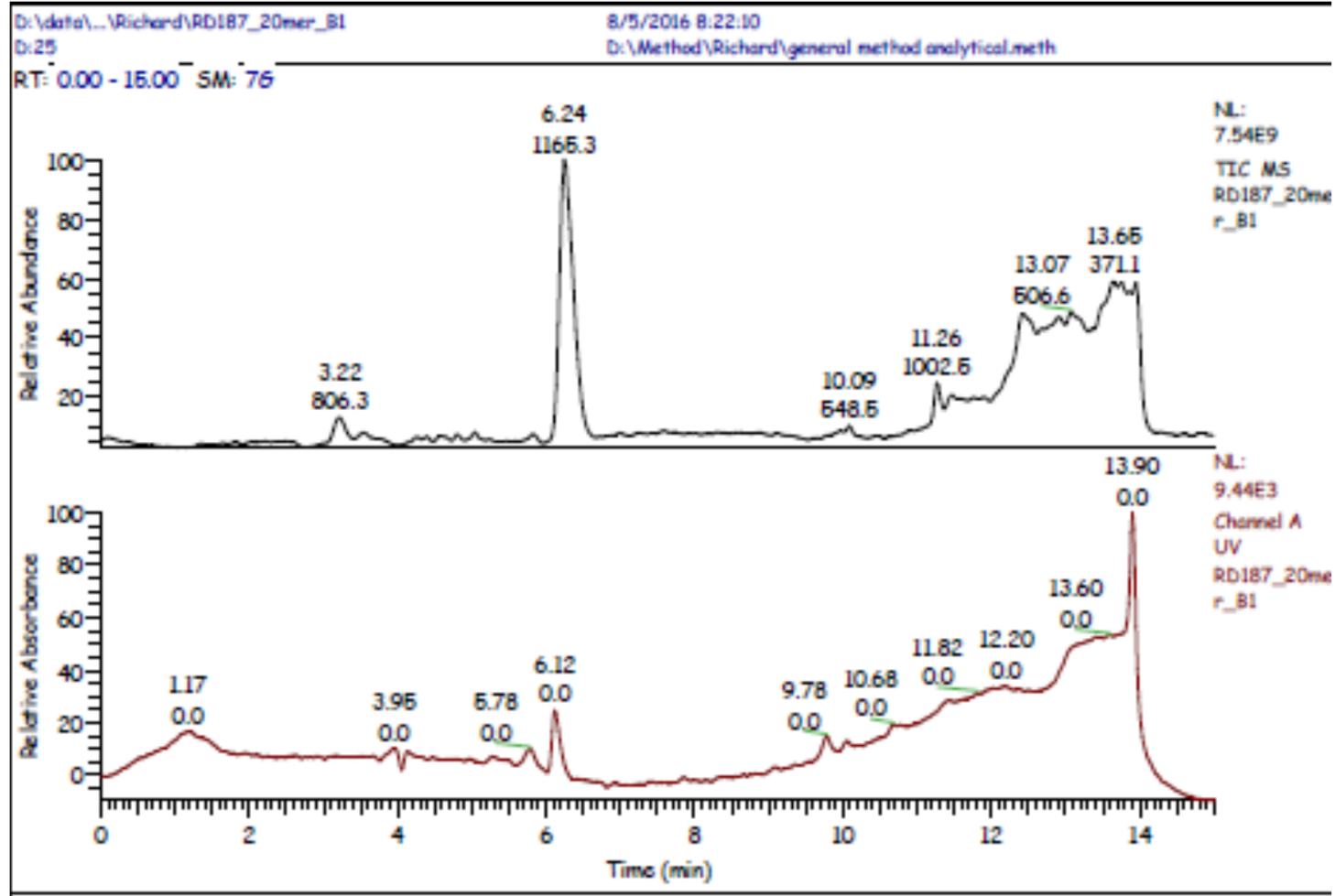

RO187_20mer_BI \#103-297 RT: 2.74-7.92 AV: 196 SM: 66 NL: 4.90E6

T: + p ESI Full $m \in[110.00-2000.00]$

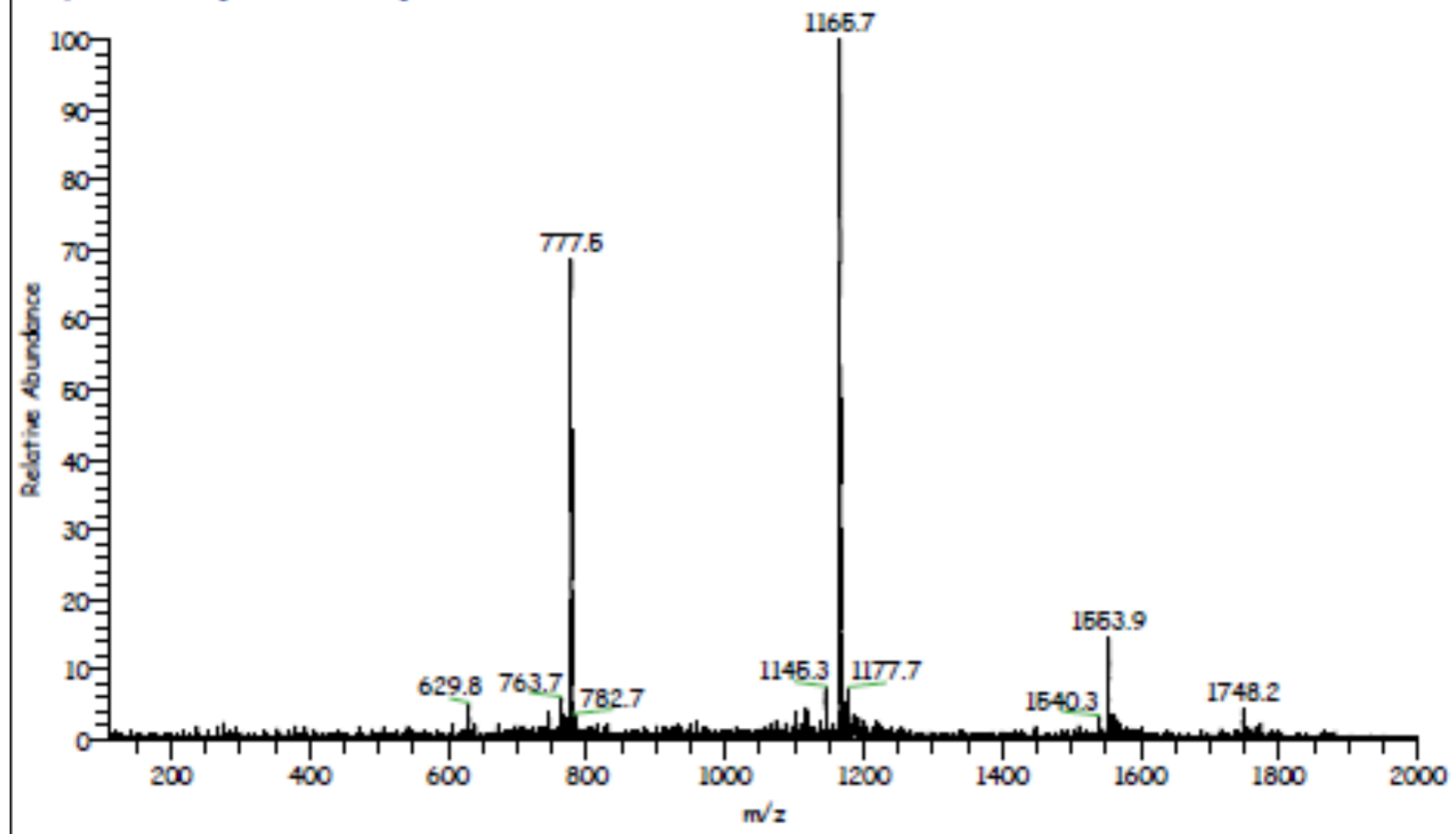

